\title{
Squid diet of emperor penguins (Aptenodytes forsteri) in the eastern Weddell Sea, Antarctica during late summer
}

\author{
UWE PIATKOWSKI and KLEMENS PÜTZ
}

\author{
Institut für Meereskunde, Universität Kiel, Düsternbrooker Weg 20, D-24105 Kiel, Germany
}

\begin{abstract}
The data presented provides new information on the distribution of Antarctic squids and on the summer diet of the emperor penguins. The diet of 58 adult emperor penguins (Aptenodytes forsteri) on the fast ice of the Drescher Inlet, Vestkapp Ice Shelf $\left(72^{\circ} 52^{\prime} \mathrm{S}, 19^{\circ} 25^{\prime} \mathrm{W}\right)$ in the eastern Weddell Sea was investigated. Prey consisted principally of squid, fish, krill, amphipods and isopods. Squids were identified by the lower beaks and allometric equations were used to estimate the squid biomass represented. Beaks occurred in $93 \%$ of the stomach samples. Each sample contained a mean of 27 beaks (range 1-206). Ninety-two percent of the squids could be identified by the lower beaks and belonged to four families (Onychoteuthidae, Psychroteuthidae, Neoteuthidae and Gonatidae). The most abundant squid was $P$ sychroteuthis glacialis which occurred in 52 samples with lower rostral lengths (LRL) ranging from 1.4-7.2 mm. Forty-five samples contained Alluroteuthis antarcticus (LRL range 1.8-5.8 mm), 17 Kondakovia longimana (LRL range 4-12.1 mm), and four Gonatus antarcticus (LRL range $4.1-6.1 \mathrm{~mm}$ ). In terms of biomass $K$. longimana was the most important species taken by the penguins comprising $50 \%$ of total estimated squid wet mass $(245348 \mathrm{~g}$ ) in 1990 and $48 \%$ in $1992(154873 \mathrm{~g})$. However, if only fresh beaks were considered for estimations of squid consumption, i.e. beaks that have been accumulated for not longer than 5-6 days in the stomachs, squid diet was of minor importance. Then total squid wet mass accounted for only $4809 \mathrm{~g}$ in 1990 and $5445 \mathrm{~g}$ in 1992 which implies that one penguin took c.30 g squid d $\mathrm{d}^{-1}$ with $P$. glacialis and $A$. antarcticus being the most important by mass. The prey composition suggests that emperor penguins take squid at the steep slope regions of the eastern Weddell Sea.
\end{abstract}

Received 5 July 1993, accepted 2 March 1994

Key words: squid, distribution, emperor penguin, Aptenodytes forsteri, diet, Antarctica

\section{Introduction}

Cephalopods play a key role in the ecosystem of the Southern Ocean (Nemoto etal. 1985). They are important prey organisms for Antarctic top predators such as albatrosses, penguins, Southern elephant seals and sperm whales (e.g. Clarke 1980, Croxall \& Prince 1980, Croxall \& Lishman 1987, Imber 1992, Rodhouse etal. 1992, Green \& Burton 1993) and total cephalopod consumption by these predators is estimated to be $c .34$ million tonnes $\mathrm{y}^{-1}$ (Clarke 1983).

Most quantitative studies on the cephalopod diet of Antarctic top predators have been conducted on subantarctic islands and on rather mobile species such as the wandering albatross and the sperm whale which are known to forage also north of the Antarctic Polar Frontal Zone (e.g. Clarke 1980, Rodhouse et al. 1987, Imber 1992). Only a few investigations have concentrated on cephalopod predators which live close to the Antarctic continent such as the Weddell seal (Lipinski \& Woyciechowski 1981, Clarke \& MacLeod 1982) and the emperor penguin (Aptenodytes forsteri)(Offredoet al. 1985, Green 1986, Offredo \& Ridoux 1986, Gales et al. 1990). Quantitative information on the importance of cephalopods to these top predators in the highAntarctic Weddell Sea is even more sparse and was only published recently by Klages (1989) on emperor penguins and Plötz et al. (1991) on Weddell seals.

Comprehensive studies on the ecology of plankton, fish and benthos of the Weddell Sea have considerably improved our knowledge of this high-Antarctic ecosystem (Hempel 1992). Information on larger free-swimming animals (nekton) and warm-blooded predators was not included in these studies, although their importance in the pelagic ecosystem of the Southern Ocean is broadly acknowledged (Nemoto et al. 1985, Ainley \& DeMaster 1990). The distribution and biology of Weddell Sea cephalopods is almost unknown, but there are indications that the glacier squid, Psychroteuthis glacialis is the dominant form in the slope regions of the south-eastern Weddell Sea (Piatkowski et al. 1990).

With the establishment of a temporary research station at Drescher Inlet in the eastern Weddell Sea, detailed studies on emperor penguins and Weddell seals have been possible in recent years. These studies contributed new information on their ecology and their importance in the Antarctic food chain (Klages 1989, Reijnders et al. 1990, Pütz \& Plötz 1991, Plötz et al. 1991).

Emperor penguins are the most efficient divers among Antarctic birds (e.g. Kooyman \& Ponganis 1990) and are known to prey heavily on high-Antarctic nekton during winter and spring when they rear their chicks (Offredo et al. 1985, Green 1986, Offredo \& Ridoux 1986, Klages 1989, Gales et al. 1990). However, the squid consumption of these birds during the Antarctic summer season has not yet been investigated 
(Ancel et al. 1992). The aim of the present study is to fill this gap. Our results also provide new information on squid abundance in the pelagic food chain of the Weddell Sea.

\section{Material and methods}

\section{Field methods}

Studies on the cephalopod diet of emperor penguins were conducted on the fast ice of the Drescher Inlet, south of Vestkapp $\left(72^{\circ} 52^{\prime} \mathrm{S}, 19^{\circ} 25^{\prime} \mathrm{W}\right)$ in the eastern Weddell Sea. This location as one of the most southerly breeding colonies of emperor penguins (about 7525 adults and 6660 chicks in October 1986) and has been described in detail by Klages \& Gerdes (1988). The colony is situated close to the steep continental slope of the eastern Weddell Sea where shallow shelf regions are almost lacking. At the mouth of the inlet, water depth exceeds $400 \mathrm{~m}$ and increases rapidly to depths of more than $3000 \mathrm{~m}$ further offshore. The Vestkapp region is influenced by the Antarctic Coastal Current, which is a branch of the East Wind Drift that flows in a south-westerly direction along the continental slope (Hellmer et al. 1985).

During recent years a temporary field station, established on the ice shelf above Drescher Inlet, has supported studies on the ecology of emperor penguins (Klages \& Gerdes 1988, Klages 1989, Pütz \& Plötz 1991) as well as on co-occurring Weddell seals (Plötzet al. 1991). For the present study stomach contents of emperor penguinswere collected from 29January-20 February 1990 and from 27 January 1992-28 February 1992 . A total of 58 adult penguins ( 29 in each year), which had apparently returned from foraging trips, were caught at the edge of the fast sea ice. The birds were transferred by sledge to a nearby tripod and weighed to the nearest $500 \mathrm{~g}$. Stomach contents were sampled using the water offloading technique described by Wilson (1984). The penguins were flushed up to three times in order to obtain the entire stomach contents. The samples were frozen for shipment to Germany and later analysis.

\section{Laboratory procedures and data analysis}

In the laboratory cephalopod mandibles ("beaks") were sorted from the stomach contents and stored in $70 \%$ ethanol. Beaks were identified to the lowest possible taxon according to Clarke $(1980,1986)$ and by comparison with material held in a reference collection at the Institut für Meereskunde, Kiel. The number of cephalopods ingested was determined from the numbers of lower beaks. Lower rostral length (LRL) of the cephalopod beaks were measured with vernier calipers to an accuracy of $0.1 \mathrm{~mm}$. Due to some inaccuracy in measuring eroded beaks and for clarity reasons we have presented beak size distributions (LRL) in mm classes. Allometric equations were used from the literature (Clarke 1986, Brown \& Klages 1987, Rodhouse 1989, Green \& Burton 1993) to relate LRL to dorsal mantle length (ML in $\mathrm{mm}$ ) and wet mass (in grammes). For beaks of Psychroteuthis glacialis and Alluroteuthis antarcticus less than $4 \mathrm{~mm}$ LRL the equations for Kondakovia longimana given by Brown \& Klages (1987) were preferred to those published in Rodhouse (1989) and Green \& Burton (1993) as they best fitted small muscular specimens.

Cephalopod beaks can be retained in seabird stomachs for several weeks (e.g. Furness et al. 1984, Jackson \& Ryan 1986), much longer than those found for fish otoliths and crustacean exoskeletons and obviously larger beaks accumulate longer in the stomach than smaller and more transparent ones. These facts can produce severe overestimations of the importance of cephalopods in the diet and have to be considered in dietary analysis for seabirds if quantitative data on squid consumption are presented (Hindell 1987, Ridoux in press). To avoid this bias and in accordance with otherworkers(Hindell 1987, van Heezik \& Seddon 1989) we have divided the squid beaks into three categories similar to the classification established by Jackson \& Ryan (1986): Type Arepresents beaks whichstill have gelatinous cartilages indicating that they are comparatively fresh, wings are mostly intact; Type B represents beaks which do not possess cartilage parts, but are still uneroded and do not show severe signs of digestion, the rostrum is still sharp but with broken and abraded wings; Type $\mathrm{C}$ represents partly eroded beaks which have very darkened and abraded wings and which are in the process of being digested, their surfaces are rounded. Type A represents beaks that have been accumulated for not longer than six days as their quality corresponds to beaks of fresh squid that were fed to the penguins and which remained for up to six days in the penguin stomachs (Pütz unpublished). According to these feeding experiments with fresh squid and the quality of beaks retrieved from the penguin stomachs after different time intervals, beaks of type $B$ have been in the stomachs for c. 10-30 days, and beaks of type $\mathrm{C}$ for more than 20 days. We feel that calculations of squid consumption derived only from type $A$ beaks will give more reliable estimations than those calculations which consider all categories of beaks. Hence, we calculated squid biomass separately for each beak category and compared the results with those numbers where squid consumption was calculated from all beaks.

\section{Results}

\section{Stomach contents analysis}

All penguins captured for the present study were adults. In summer 1990 their mean body mass was $23.1 \mathrm{~kg}$ (range $17-31 \mathrm{~kg}, n=29$ ); in 1992 it was slightly higher with $27.7 \mathrm{~kg}$ (range $14-34 \mathrm{~kg}, n=29$ ), although this difference was not significant (Mann-Whitney $U$-test, $p>0.05$ ).

The occurrences of major prey classes in the penguin stomachs are summarized in Table I. Squid were the most commonly encountered prey and were found in $90 \%$ of the stomachs in 1990 , and in $97 \%$ in 1992. Each stomach contained a mean of 27 lowersquid beaks (range 1-206). Aftersquid were fish which occurred in $86 \%$ of the stomachs in 1990 and in $62 \%$ in 1992, followed by krill(Euphausia superba), amphipods and isopods. 
Table I. Occurrence of major prey classes in stomach contents of emperor penguins (1990: $n=29 ; 1992: n=29$ ) at Drescher Inlet during late summer.

\begin{tabular}{lccc}
\hline Prey class & $\begin{array}{c}1990 \\
\text { Numbers (\%) }\end{array}$ & $\begin{array}{c}1992 \\
\text { Numbers (\%) }\end{array}$ & $\begin{array}{c}1990+1992 \\
\text { Numbers (\%) }\end{array}$ \\
\hline Squid & $26(90)$ & $28(97)$ & $54(93)$ \\
Fish & $25(86)$ & $18(62)$ & $43(74)$ \\
Krill & $22(76)$ & $17(59)$ & $39(67)$ \\
Amphipods & $20(69)$ & $12(41)$ & $32(55)$ \\
Isopods & $9(31)$ & $4(14)$ & $13(22)$ \\
\hline
\end{tabular}

\section{Cephalopod prey}

A total of 1409 lower beaks were found of which $1290(92 \%)$ were identified and measured. In 1990, 691 lower beaks were found in $89.7 \%$ of the stomachs; 718 lower beaks occurred in $96.6 \%$ of the 1992 samples. In bothyears beaks of Psychroteuthis glacialis were the most abundant fraction. The frequency of occurrence and abundance of lower beaks from eachcephalopod species is shown in Table II, together with the estimated wet mass represented by all identified beaks.

Size distributions of lower rostral length (LRL) for the three major squid species $P$. glacialis, Alluroteuthis antarcticus and Kondakovia longimana are shown in Fig. 1a-c. LRL for P. glacialis ranged from $1.4-7.2 \mathrm{~mm}$ (size classes $1-7 \mathrm{~mm}$; Fig. 1a) which represents squid of $30-357 \mathrm{~mm}$ dorsal mantle length(ML) and 3-993 g. A. antarcticus had LRL from 1.8-5.8 $\mathrm{mm}$ (size classes $1-5 \mathrm{~mm}$; Fig.1b) representing specimens of 46-177 $\mathrm{mm} \mathrm{ML}$ and 5-811 g. K. longimana ranged from 4-12.1 mm LRL (size classes 4-12 mm; Fig. 1c). These represent animals of $129-465 \mathrm{~mm} \mathrm{ML}$ and $56-1845 \mathrm{~g}$. Only five Gonatus antarcticus were identified from the stomach contents. Their LRL fell in the $4-6 \mathrm{~mm}$ size classes representing animals of $132-231 \mathrm{~mm} \mathrm{ML}$ and $57-250 \mathrm{~g}$. Only in the case of $K$. longimana beak size varied significantly between the two years with mean LRL of $8.6 \mathrm{~mm}$ in 1990 and $7.3 \mathrm{~mm}$ in 1992
(Mann-Whitney $U$-test, $p<0.05$ ).

In terms of estimated wet mass and if all accumulated beaks are considered the onychoteuthid $K$. longimana dominated the samples with a total of $122737 \mathrm{~g}(50 \%)$ in 1990 and $74414 \mathrm{~g}$ (48\%) in 1992 followed by A antarcticus with $90294 \mathrm{~g}(36.8 \%)$ in 1990 and $44680 \mathrm{~g} \mathrm{(28.9 \% )} \mathrm{in} \mathrm{1992.} \mathrm{The} \mathrm{lower} \mathrm{value} \mathrm{for}$ $K$. longimana in 1992 was caused by the absence of big specimens during the 1992 season (Fig. 1c, Table II). P. glacialis was preyed upon at very similar amounts irrespective of the year studied (32 $010 \mathrm{~g}$ in 1990, 35183 in 1992). Its increase in \% mass was a consequence of decreases in $K$. longimana and $A$. antarcticus estimated wet masses (39\% decrease for $K$. longimana and $50 \%$ decrease for $A$. antarcticus between 1990 and 1992). These in turn are due to the smaller size of the former and the lower abundance of the latter (Table II). Estimated total squid biomass taken by the penguins was considerably higher in 1990 (245 348 g) than in 1992 (154 $873 \mathrm{~g}$ ). The average amount of squid diet taken per penguin was $8460 \mathrm{~g}(n=29)$ in 1990 , and $5340 \mathrm{~g}(n=29)$ in 1992 if all categories of beaks were considered. However, these numbers are considerable overestimations and strongly biased due to the long retention time of squid beaks within the birds stomachs. As outlined earlier, the wet mass was calculated separately for each type class (Fig. 2) and species (Table III). Only 87 beaks fell in the type A category (fresh beaks), whereas 679 beaks belonged to type B (beaks of an age of 10-30 days) and 524 beaks to type $\mathrm{C}$ (beaks older than 20 days). In both years beaks of $P$. glacialis and $A$. antarcticus contributed the major part of fresh beaks (Fig. 2). In contrast, beaks of $K$. longimana were mostly old beaks of type C ( $96 \%$ in 1990, 85\% in 1992; Table III; Fig. 2). If only beaks of type $A$ were considered for the estimates then squid consumed by the birds within the last six days accounted for only $4809 \mathrm{~g}$ in 1990 and $5445 \mathrm{~g}$ in 1992 . This would mean $166 \mathrm{~g}$ and $188 \mathrm{~g}$ for each bird during six days and only c. $30 \mathrm{~g}$ for each bird and day during the summer season. Additionally

Table II. Aptenodytes forsteri. Frequency of occurrence and relative abundance of identified lower squid beaks from stomach contents of adult specimens and estimated wet mass represented by beaks.

\begin{tabular}{|c|c|c|c|c|c|c|c|}
\hline \multirow[t]{2}{*}{ Squid species } & \multicolumn{2}{|c|}{ Frequency of occurrence } & \multicolumn{2}{|c|}{ Abundance } & \multicolumn{2}{|c|}{ Estimated wet mass [g] } & \multirow[b]{2}{*}{ Total $[\%$} \\
\hline & No. & $\%$ & No. & $\%$ & Mean & Total & \\
\hline \multicolumn{8}{|l|}{1990 (29 stomach contents) } \\
\hline Psychroteuthis glacialis & 25 & 86.2 & 255 & 36.9 & 126 & 32010 & 13.1 \\
\hline Alluroteuthis antarcticus & 22 & 75.9 & 249 & 36.0 & 363 & 90294 & 36.8 \\
\hline Kondakovia longimana & 8 & 27.6 & 136 & 19.7 & 903 & 122737 & 50.0 \\
\hline Gonatus antarcticus & 2 & 6.9 & 2 & 0.3 & 154 & 307 & 0.1 \\
\hline Unidentified & 7 & 24.1 & 49 & 7.1 & - & - & - \\
\hline Totals & 26 & 89.7 & 691 & 100.0 & 382 & 245348 & 100.0 \\
\hline \multicolumn{8}{|l|}{1992 (29 stomach contents) } \\
\hline Psychroteuthis glacialis & 27 & 93.1 & 322 & 44.9 & 109 & 35183 & 22.7 \\
\hline Alluroteuthis antarcticus & 23 & 79.3 & 140 & 19.5 & 319 & 44680 & 28.9 \\
\hline Kondakovia longimana & 9 & 31.0 & 183 & 25.5 & 407 & 74414 & 48.0 \\
\hline Gonatus antarcticus & 2 & 6.9 & 3 & 0.4 & 199 & 596 & 0.4 \\
\hline Unidentified & 12 & 41.4 & 70 & 9.7 & - & - & - \\
\hline Totals & 28 & 96.6 & 718 & 100.0 & 239 & 154873 & 100.0 \\
\hline
\end{tabular}


Psychroteuthis glacialis

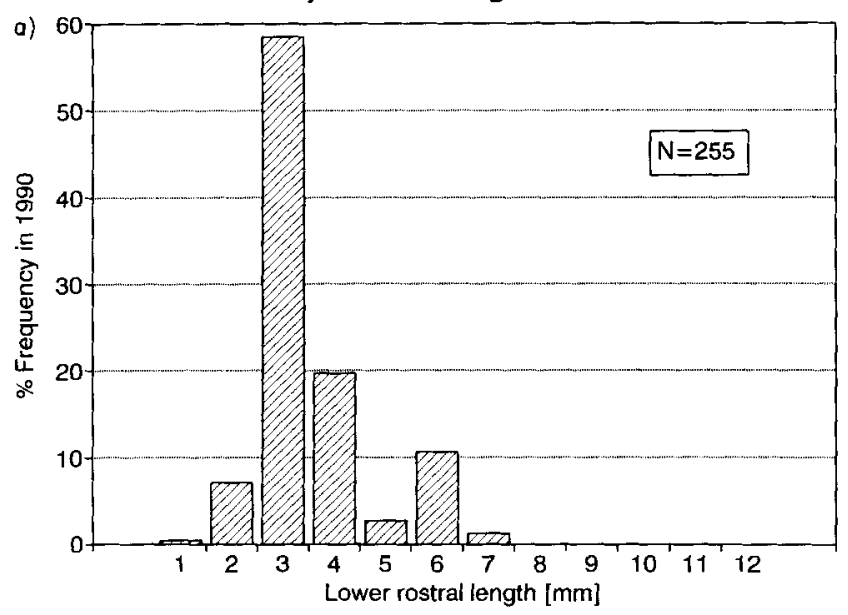

Aluroteuthis antarcticus

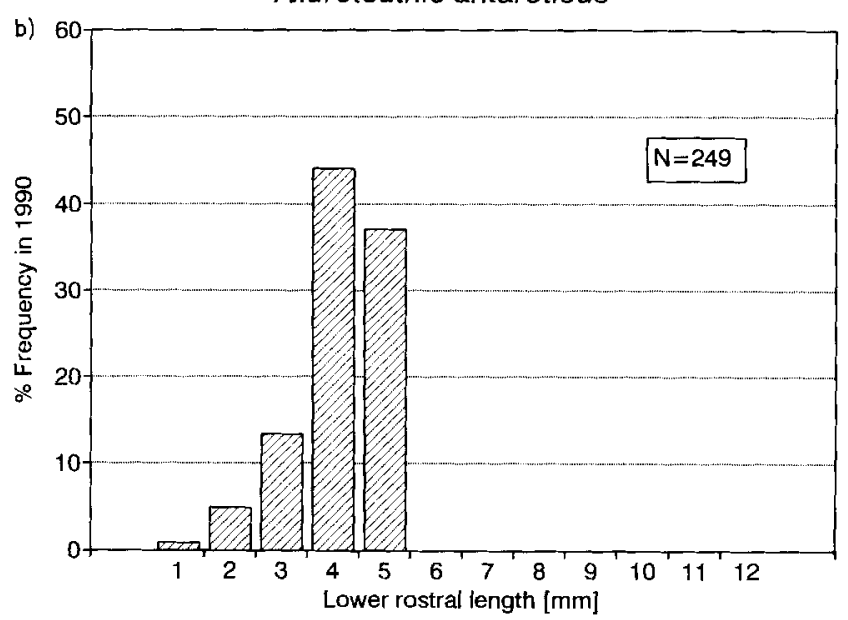

Kondakovia longimana

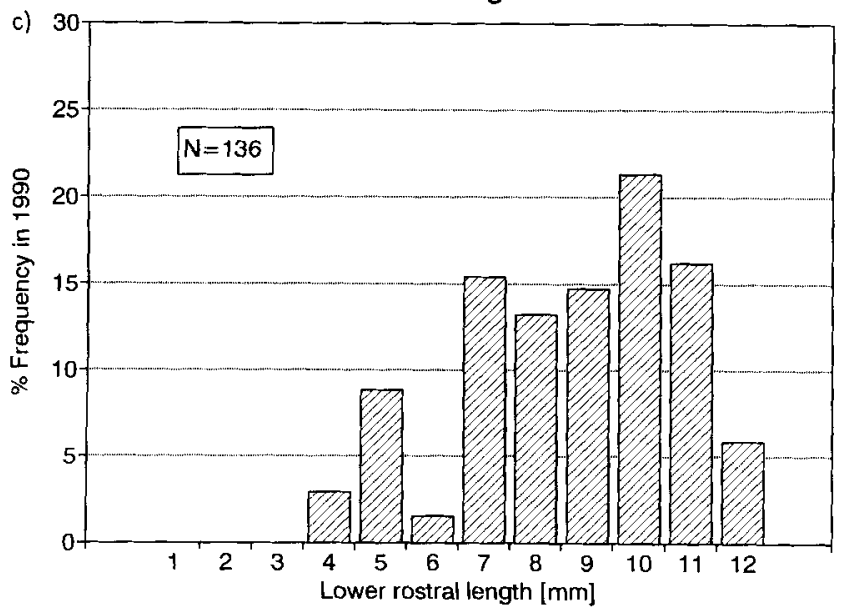

Psychroteuthis glacialis

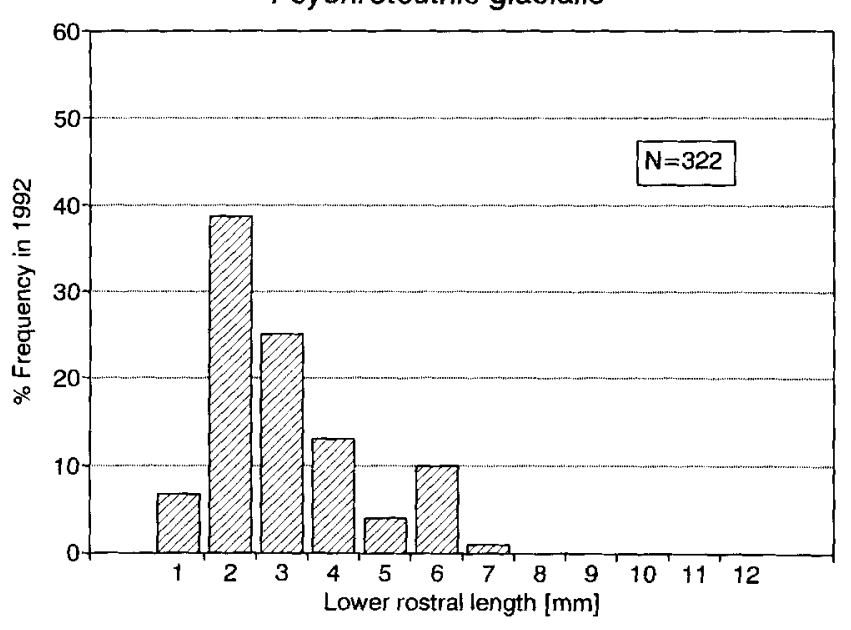

Alluroteuthis antarcticus

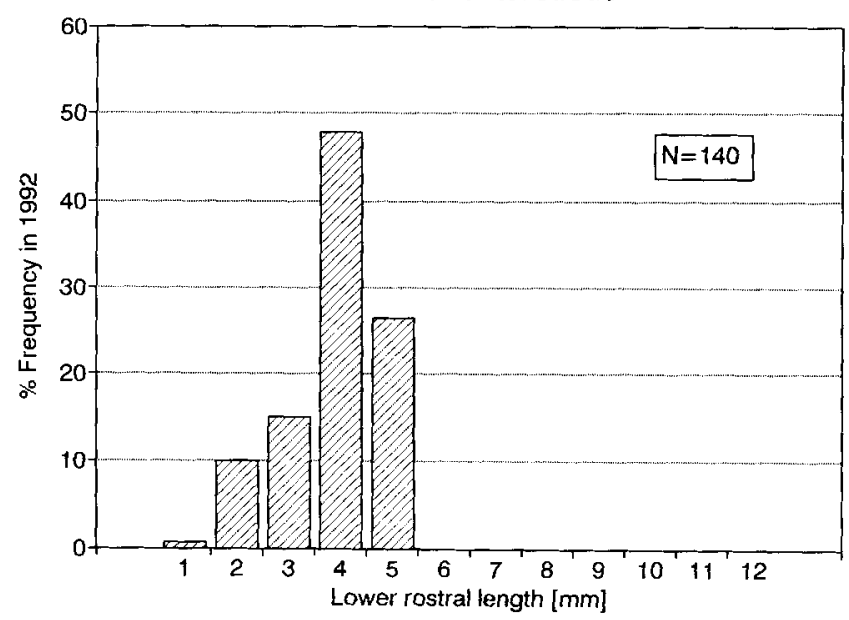

Kondakovia longimana

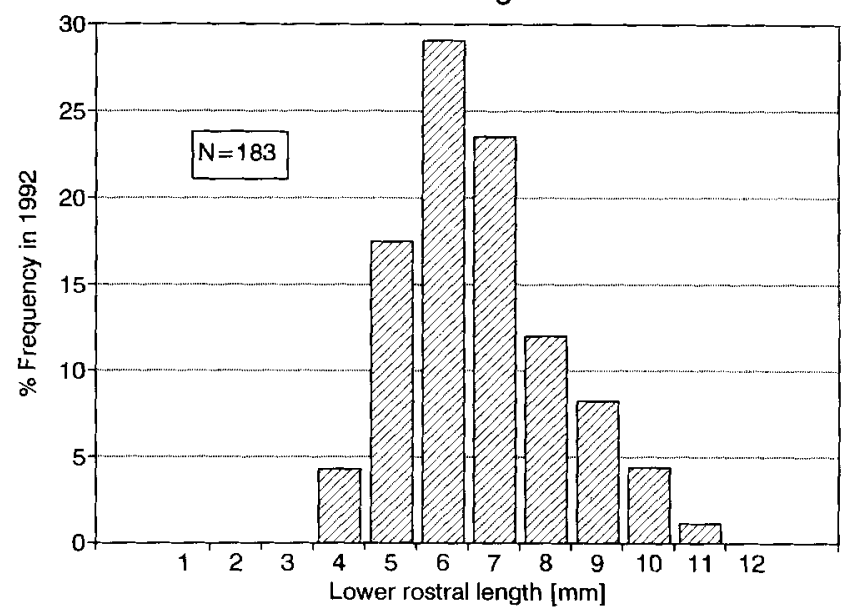

Fig. 1. Prey size frequency distribution of major cephalopod species consumed by emperor penguins in 1990 and 1992 . a. Psychroteuthis glacialis, b. Alluroteuthis antarcticus, c. Kondakovia longimana. 
the estimated squid diet composition was strongly modified when different degradation classes were considered (Table III).

\section{Discussion}

According to the occurrence of major prey classes in the summer diet of emperor penguins at Drescher Inlet squid were the most frequent prey being found in $93 \%$ of the stomachs. This is surprising as fish and crustaceans (mainly Euphausia superba) have been reported to be the principal diet of emperor penguins during the breeding seasons of the birds in winter and spring (Klages 1989, Gales et al. 1990). Our results show that fish and krill only ranked second and third with $74 \%$ and $67 \%$ in frequency of occurrence. Squid are probably more abundant during summer. In particular, the glacier squid Psychroteuthis glacialis, is a frequent component of the summerhigh-Antarctic nekton community as indicated by its regular occurrence in benthopelagic trawls along the slope of the Antarctic continent (Piatkowski et al. 1990, Piatkowski personal observation). Furthermore, it has been suggested that during winter and spring, euphausiids are associated with the underside of sea ice, where they can form dense concentrations which are easily accessible to the penguins (Klages 1989). These concentrations are more dispersed during summer when the sea ice melts and is transported away from the coastal region to areas where emperor penguins are not abundant. Squid, and also fish (mainly Pleuragramma antarcticum), are generally found in dense concentrations over the continental slope and inner-shelf depressions at depths below $200 \mathrm{~m}$ (Hubold 1984, Piatkowski $e t$ al. 1990) which are common feeding grounds for emperor penguins and Weddell seals (Plötz 1986, Klages 1989). Presumably, emperor penguins switch to this diet in the summer when krill is not so abundant in the coastal region. Since emperorpenguins are very effective divers(Kooyman \& Ponganis 1990, Ancel et al. 1992), P. antarcticum and mesopelagic and benthopelagic organisms like $P$. glacialis are presumably easily obtainable prey.

If all beak categories are considered for the estimation of squid consumption, then the emperor penguins took $245348 \mathrm{~g}$ in 1990 (29 birds), and 154873 g in 1992 (29 birds). These comparatively high amounts would indicate that the mean squid biomass calculated from all accumulated beaks in the stomach contents was $8460 \mathrm{~g}$ in 1990 , and $5340 \mathrm{~g}$ in 1992 per bird. However, in accordance with Fumess et al. (1984), Hindell (1987) and Ridoux (in press) we believe that the importance of squid is largely overemphasized if squid beaks are used to reconstruct original meal volumes of birds without separating them into categories which reveal their retention time in the birds' stomach. As shown for Kondakovia longimana the percentage of partly digested beaks is extremely high (Table III; Fig. 2). In contrast, $P$. glacialis has the highest percentage of relatively fresh beaks (Types A and B). Furness et al. (1984) found that relatively uneroded beaks of ommastrephid squid resided for at least 50 days in a shy albatross (Diomedea cauta). Hence, we consider that "older" squid beaks of Type B and C have been
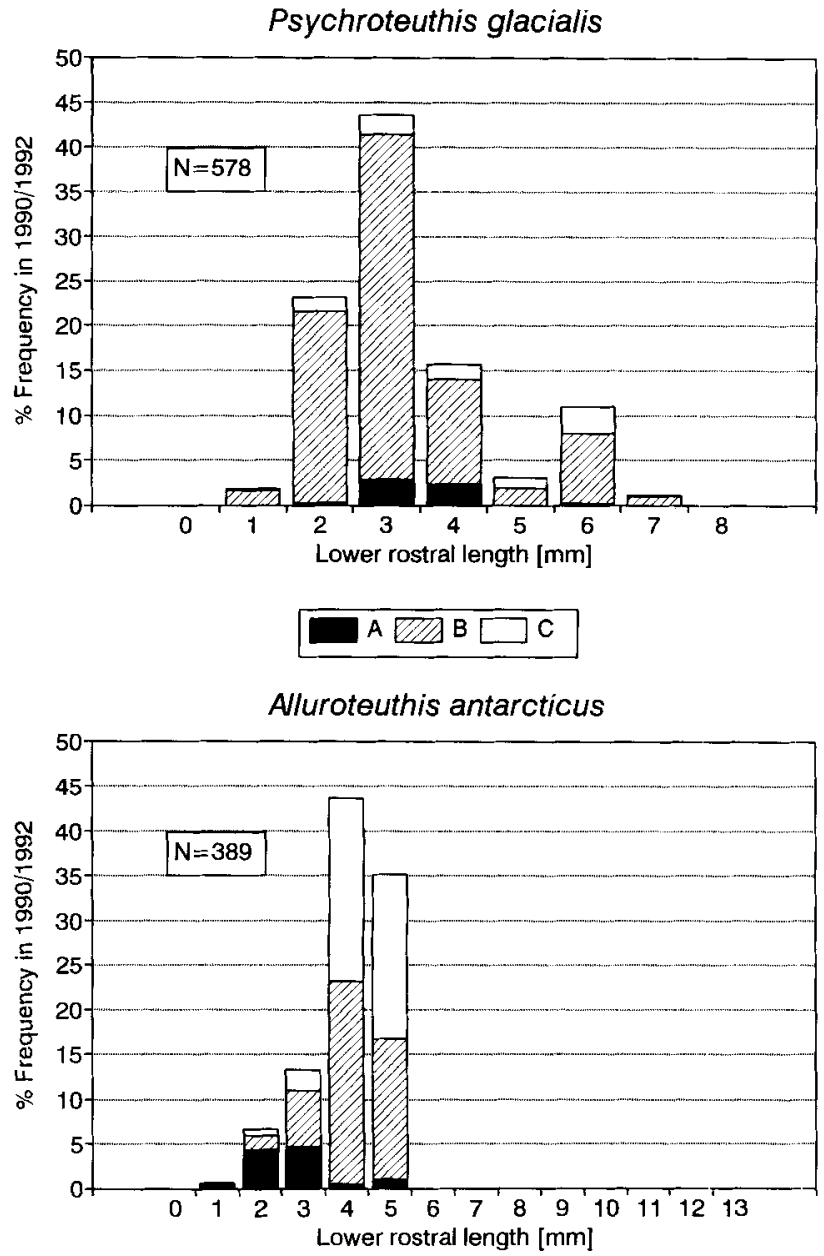

A $\square \square$

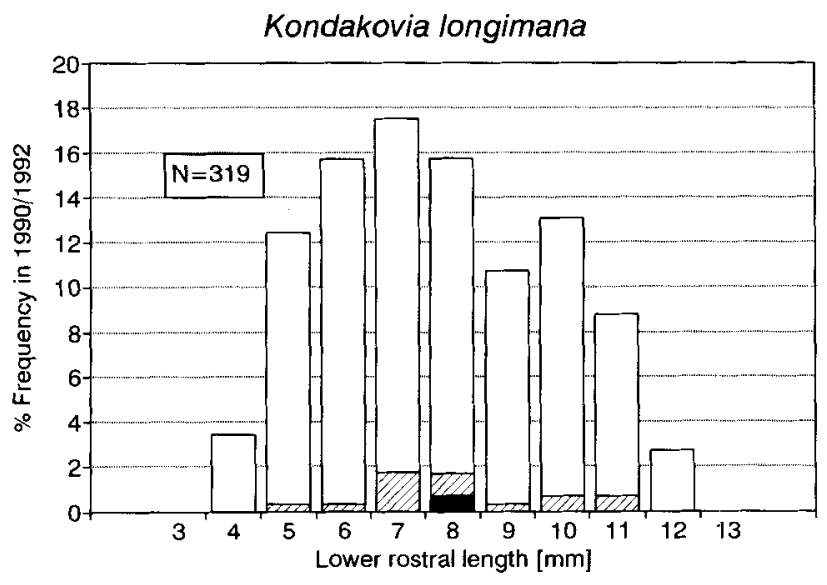

$\mathrm{A} \square \mathrm{BC}$

Fig. 2. Prey size frequency distribution of major cephalopod species consumed by emperor penguins. Data for 1990 and 1992 are combined and differentiated into three categories. Type A: beaks in fresh condition; Type B: beaks without cartilage parts, but still relatively uneroded; Type C: partly eroded and digested beaks. 
Table III. Numbers of identified squid beaks from stomach contents of adult emperor penguins and estimated wet mass represented by beaks. Beaks are separated into degradation classes A, B and C.

\begin{tabular}{|c|c|c|c|c|c|c|c|c|c|c|c|c|}
\hline \multirow[t]{2}{*}{ Squid species } & \multicolumn{4}{|c|}{ Type A } & \multicolumn{4}{|c|}{ Type B } & \multicolumn{4}{|c|}{ Type C } \\
\hline & No. & $\begin{array}{c}\text { Mass } \\
\text { (g) }\end{array}$ & $\begin{array}{c}\% \\
\text { type } \\
\text { A }\end{array}$ & $\begin{array}{c}\% \\
\text { diet } \\
\text { mass }\end{array}$ & No. & $\begin{array}{c}\text { Mass } \\
(\mathrm{g})\end{array}$ & $\begin{array}{c}\% \\
\text { type } \\
\mathrm{B}\end{array}$ & $\begin{array}{c}\% \\
\text { diet } \\
\text { mass }\end{array}$ & No. & $\begin{array}{l}\text { Mass } \\
\text { (g) }\end{array}$ & $\begin{array}{c}\% \\
\text { type } \\
\mathrm{C}\end{array}$ & $\begin{array}{c}\% \\
\text { diet } \\
\text { mass }\end{array}$ \\
\hline \multicolumn{13}{|l|}{1990 (29 stomach contents) } \\
\hline Psychroteuthis glacialis & 25 & 1500 & 5 & 31 & 196 & 25601 & 80 & 40 & 34 & 4909 & 15 & 3 \\
\hline Alluroteuthis antarcticus & 25 & 3309 & 4 & 69 & 100 & 34330 & 38 & 53 & 124 & 52655 & 58 & 30 \\
\hline Kondakovia longimana & 0 & 0 & 0 & 0 & 3 & 4376 & 4 & 7 & 133 & 118361 & 96 & 67 \\
\hline Gonatus antarcticus & 0 & 0 & 0 & 0 & 0 & 0 & 0 & 0 & 2 & 307 & 100 & $<1$ \\
\hline Total & 50 & 4809 & 2 & 100 & 299 & 64307 & 26 & 100 & 293 & 176232 & 72 & 100 \\
\hline \multicolumn{13}{|l|}{1992 (29 stomach contents) } \\
\hline Psychroteuthis glacialis & 9 & 1115 & 3 & 20 & 285 & 23939 & 68 & 39 & 28 & 10129 & 29 & 12 \\
\hline Alluroteuthis antarcticus & 22 & 791 & 2 & 15 & 79 & 30284 & 68 & 49 & 39 & 13605 & 30 & 15 \\
\hline Kondakovia longimana & 6 & 3539 & 5 & 65 & 16 & 7746 & 10 & 12 & 161 & 63129 & 85 & 72 \\
\hline Gonatus antarcticus & 0 & 0 & 0 & 0 & 0 & 0 & 0 & 0 & 3 & 596 & 100 & 1 \\
\hline Total & 37 & 5445 & 4 & 100 & 380 & 61969 & 40 & 100 & 231 & 87459 & 56 & 100 \\
\hline
\end{tabular}

accumulated in the penguin stomachs for over several weeks, maybe months. They are of no use in estimating actual consumption rates of squid and should be excluded from any prey biomass calculations. As an alternative we suggest only fresh beaks (our type A) are used for the calculations as they more realistically represent the penguins' diet during the days before sampling. Using this, we calculated the total amount of squid diet to be much lower with only $4809 \mathrm{~g}$ in 1990 and 5445 gin 1992 (Table III). These amounts suggest a squid consumption of $c .30 \mathrm{~g} \mathrm{~d}^{-1}$ per penguin during the summer season with $P$. glacialis and $A$. antarcticus being the most abundant squid prey. It also clarifies the role of $K$. longimana which overwhelmingly dominated both by numbers and mass the composition of type $\mathrm{C}$ eroded beaks (Table III). This suggests that the main predation on $K$. longimana took place more than fourweeksbefore the sampling period. Shortly before sampling the species was of minor importance in the foraging area near the colony. Assuming a constant squid predation rate 10 times more beaks in B and C conditions would normally be expected. These accumulate for at least 50 days whereas beaks in condition A remain fresh for only about 5-6 days. These conclusions derived from the analysis of differentiated squid beaks strongly indicate that estimations of squid diet should be treated with great caution, if they are calculated from beaks in stomach contents.

On the other hand, it has been shown that Southern Ocean squid is a prey of high nutritive value and high utilization efficiency (Adams 1984, Cherel \& Ridoux 1992). Calorific values for the Antarctic onychoteuthid squid, Moroteuthis ingens, which is similar to the species in our study, are about $24 \mathrm{~kJ} \mathrm{~g}^{-1}$ dry mass (Cherel \& Ridoux 1992), and are in the same range to those measured for mesopelagic fish (22-26 kJ g $\mathrm{dry}^{-1}$ mass; Cherel \& Ridoux 1992). The authors also found that the squid contains higher percentages of protein ( $81 \%$ dry mass) than mesopelagic fish (47-57\% dry mass). Therefore, it is not surprising that emperor penguins are attracted to prey upon muscular squid of high nutritive value. This is of particular importance in late summer when the penguins aggregate at the prospective breeding sites to accumulate energy reserves for the approaching breeding season.

Our data show that $K$. longimana was an important component in the penguin diet. It was not reported, however, from the stomach content analysis of emperor penguins conducted by Klages (1989) during October and November 1986 at the same location. Probably, the distribution of $K$. longimana extends further to the south during the summer. During the sampling period $P$. glacialis and $A$. antarcticus seemed to be the most important squids in terms of biomass. They are the only muscular species that have been sampled recently by benthopelagic trawls in the eastern part of the Weddell Sea (Piatkowski et al.1990). All squids reported in the present study are known to occur in the high-Antarctic (Roper et al. 1985, Nesis 1988). The large numbers of these pelagic cephalopods, indicated by the presence of beaks, provide new information on their biogeography in the Weddell Sea. There is evidence that they are important links in the pelagic food web of the highAntarctic. Squid are known to prey heavily on euphausiids (Nemoto et al. 1988, Kear 1992), and their importance as summer diet for emperor penguins has been documented in the present study. Further investigations are now needed which will focus on reproduction and growth of Antarctic squids to obtain a better understanding of their general biology.

\section{Acknowledgements}

We would like to thank R. Steinmetz for his help in the field, V. Stenzel for her help in analysing the stomach contents and R.P. Wilson for improving the English. Thanks are also due to J. Plötz, H. Bornemann and J. Ulbricht. We are grateful to $V$. Ridoux and an anonymous referee who offered critical comments and many useful suggestions for improving the manuscript. This study was supported by the Deutsche 
Forschungsgemeinschaft and the Alfred-Wegener-Institut für Polar- und Meeresforschung, Bremerhaven. Financial support for presenting this research at the Southern Ocean Cephalopods Symposium in Cambridge was obtained from the BritishGerman Academic Research Collaboration Programme(ARC) of the British Council and the Deutscher Akademischer Austauschdienst (Grant No. AT 313-ARC-VI-92/65).

\section{References}

ADAMS, N.J. 1984. Utilization efficiency of a squid diet by adult king penguins (Aptenodytes patagonicus). Auk, 101, 884-886.

AINLEY, D.G. \& DEMASTER, D.P. 1990. The upper trophic levels in polar marine ecosystems. In SMTH JR, W.O. ed Polar Oceanography. Part B. Chemistry, Biology, and Geology. San Diego: Academic Press, 599-630.

Ancel, A., Koomman, G.L., Ponganis, P.J., Gendner, J.P., Lignon, J., Mestre, X., Huin, N., Thorson, P.H., Robisson, P. \& Le MaHo, Y. 1992. Foraging behaviour of emperor penguins as a resource detector in winter and summer. Nature, 360, 336-339.

Brown, C.R. \& KLAGES, N.T. 1987. Seasonal and annual variation in diets of Macaroni (Eudyptes chrysolophus chrysolophus) and southern rockhopper (E. chrysocome chrysochome) penguins at subantarctic Marion Island. Journal of Zoology, London, 212, 7-28.

Cherel, Y. \& Ridoux, V. 1992. Prey species and nutritive value of food fed during summer to king penguin Aptenodytes patagonica chicks at Possession Island, Crozet Archipelago. Ibis, 134, 118-127.

CLARKE, M.R. 1980. Cephalopoda in the diet of sperm whales of the Southern Ocean hemisphere and their bearing on sperm whale biology. Discovery Reports, 37, 1-324.

CLARKE, M.R. 1983. Cephalopod biomass-estimation from predation.Memoirs of the National Museum of Victoria, 44, 85-107.

CLARKE, M.R. 1986. A handbook for the identification of cephalopod beaks. Oxford: Clarendon, $273 \mathrm{pp}$.

Clarke, M.R. \& MacLeod, N. 1982. Cephalopod remains in the stomachs of eight Weddell seals. British Antarctic Survey Bulletin, No. 57, 33-40.

Croxall, J.P. \& Prince, P.A. 1980. Food, feeding ecology and ecological segregation of seabirds at South Georgia. Biological Journal of the Linnean Society, 14, 103-131.

Croxall, J.P. \& Lishmav, G.S. 1987. The food and feeding ecology of penguins. In Croxall, J.P. ed. Seabirds: Feeding ecology and role in marine ecosystems. Cambridge: Cambridge University Press, 408 pp.

FurNess, B.L., Laugksch, R.C. \& DuFry, D.C. 1984. Cephalopod beaks and studies of seabird diets. $A u k, 101,619$.

Gaies, N.J., KLages, N.T.W., Wiwams, R. \& WogmiER, E.J.1990. The diet of the emperorpenguin, Aptenodytes forsteri, in Amanda Bay, Princess Elizabeth Land, Antarctica. Antarctic Science, 2, 23-28.

Green, K. 1986. Food of the emperor penguin Aptenodytes forsteri on the Antarctic fast ice edge in late winter and early spring. Polar Biology, 6, 187-188.

Green, K. \& BURTON, H.R. 1993. Comparison of the stomach contents of southem elephant seals, Mirounga leonina, at Macquarie and Heard Islands. Marine Mammal Science, 9, 10-22.

HeEZTK, Y. vaN \& SEDDON, P. 1989. Stomach sampling in the yellow-eyed penguin: erosion of otoliths and squid beaks. Journal of Field Ornithology, 60, 451-458.

Hewmer, H.H., Bersch, M., Auosten, E. \& Grabemann, I. 1985. The Southern Ocean. Asurvey of oceanographic and marine meteorological research work. Berichte zur Polarforschung, 26, 1-115.

HEMPEI, G. ed. 1992. Weddell Sea Ecology. Results of EPOS, European Polarstern Study. Berlin: Springer-Verlag, 333 pp.

HINDELL, M.A. 1987. The diet of the king penguin Aptenodytes patagonicus at Macquarie Island. Ibis, 130, 193-203.

HuboL, G. 1984. Spatial distribution of Pleuragramma antarcticum (Pisces: Nototheniidae) near the Filchner- and Larsen Ice Shelves (Weddell Sea/
Antarctica). Polar Biology, 3, 231-236.

IMBER, M.J. 1992. Cephalopods eaten by wandering albatrosses (Diomedea exulans L.) breeding at six circumpolar localities. Journal of the Royal Society of New Zealand, 22, 243-263.

JACKSON, S. \& RYAN, P.G. 1986. Differential digestion rates of prey by whitechinned petrels (Procellaria aequinoctialis). Auk, 103, 617-619.

KEAR, A.J. 1992. The diet of Antarctic squid: comparison of conventional and serological gut contents analyses. Journal of Experimental Marine Biology and Ecology, 156, 161-178.

KLAGES, N.T.W. 1989. Food and feeding ecology of emperor penguins in the eastern Weddell Sea. Polar Biology, 9, 385-390.

KLAGES, N.T.W. \& GERDES, D. 1988. A little known colony of emperor penguins on the coast of the eastern Weddell Sea. South African Journal of Antarctic Research, 18, 18-20.

KoOYMan, G.L. \& Ponganis, P.J. 1990. Behavior and physiology of diving in emperor and king penguins. In DAVIS, L.S. \& DARBY, J.eds. Penguin biology. New York: Academic Press, 229-243.

LIPINSK, M. \& WoYciechowsK, M. 1981. Cephalopods in the food of Weddell seals from the Admiralty Bay (King George Island, South Shetland Islands). Polish Polar Research, 2, 163-167.

Nemoto, T., Okryama, M. \& Takahash, M. 1985. Aspects of the roles of squid in food chains of the marine Antarctic ecosystems. In SIEGFRIED, W.R., CONDY, P.R. \& Laws, R.M. eds. Antarctic nutrient cycles and food webs. Proceedings of the 4th SCAR Symposium of Antarctic Biology. Berlin: Springer-Verlag, 415-420.

Nemoto, T., OkJYaMa, M., Iwasaki, N. \& KikuchI, T. 1988. Squid as predators on krill (Euphausia superba) and prey for sperm whales in the Southern Ocean. In SAHRHAGE, D. ed. Antarctic Ocean and resources variability. Berlin: Springer-Verlag, pp. 292-296.

NesIs, K.N. 1988. Cephalopods of the world. Neptune City, N.J.: T.F.H. Publications, $351 \mathrm{pp}$.

OFFREDO, C. \& RDOUX, V. 1986. The diet of emperor penguins Aptenodytes forsteri in Adélie Land, Antarctica. Ibis, 128, 409-413.

OfFRedo, C., Ridoux, V. \& CLARKE, M.R. 1985. Cephalopods in the diets of emperor and Adélie penguins in Adélie Land, Antarctica. Marine Biology, 86, 199-202.

PlatxowskJ, U., White, M. \& Dmamer, W. 1990. Micronekton of the Weddell Sea: Distribution and abundance. In ARNTZ, W., ERNST, W. \& HEMFEL, I eds. The ExpeditionANTARKTISVI/4 (EPOSleg3) and VII/S ofRV "Polarstern" in 1989. Berichte zur Polarforschung, 68, 73-81.

PLơrz, J. 1986. Summer diet of Weddell seals (Leptonychotes weddellii) in the eastern and southern Weddell Sea, Antarctica. Polar Biolgy, 6, 97-102.

PLOTZ,J.,EKAU, W. \& REINDERS, P.J.H. 1991. Diet of Weddell seals Leptonychotes weddellii at Vestkapp, eastern Weddell Sea (Antarctica), in relation to local food supply. Marine Mammal Science, 7, 136-144.

P'Tz, K. \& PLorz, J. 1991. Moulting starvation in emperorpenguin (Aptenodytes forsteri) chicks. Polar Biology, 11, 253-258.

RELNDERS, P.J.H., PLöTZ, J., ZEGERS, J. \& GRÄFE, M. 1990. Breeding biology of Weddell seals (Leptonychotes weddellii) at Drescher Inlet, Riiser Larsen Ice Shelf, Antarctica. Polar Biology, 10, 301-306.

RIDOUX, V. in press. The diets and dietary segregation of seabirds at the subantarctic Crozet Islands. Marine Ornithology, 20.

RoDHOUSE, P.G. 1989. Pelagic cephalopods caught by nets during the Antarctic research cruises of the 'Polarstern' and 'Walther Herwig', 1985-1987. Archiv fü Fischereiwissenschaft, 39 (Beiheft 1), 111-121.

Rodhouse, P.G., ClaRKE, M.R. \& MurRay, A.W.A. 1987. Cephalopod prey of the wandering albatross Diomedea exulans. Marine Biology, 96, 1-10.

Rodhouse, P.G., Arnbom, T.R., Fedak, M.A., Yeatman, J. \& Murray, A.W.A. 1992. Cephalopod prey of the southern elephant seal, Mirounga leonina $L$. Canadian Journal of Zoology, 70, 1007-1015.

Roper, C.F.E., SWEENEY, M.J. \& CLARKE, M.R. 1985. Cephalopods. In FisCHER, W. \& HuREAU, J.C. eds. FAO species identification sheets for fishery purposes. Southern Ocean (Fishing areas 48, 58 and 88) (CCAMLR Convention area). Rome: FAO, Vol.1, 117-205.

WILSON, R.P.1984. An improved stomach pump for penguins and other seabirds. Journal of Field Ornithology, 55, 109-112. 